\title{
Capítulo III - A linguagem em seu contexto histórico e político
}

\author{
Anita Helena Schlesener
}

\section{SciELO Books / SciELO Livros / SciELO Libros}

SCHLESENER, AH. A linguagem em seu contexto histórico e político. In: Grilhões invisíveis: as dimensões da ideologia, as condições de subalternidade e a educação em Gramsci [online]. Ponta Grossa: Editora UEPG, 2016, pp. 93-133. ISBN 978-85-7798-234-9. Available from: doi: 10.7476/9788577982349.0004. Also available in ePUB from: http://books.scielo.org/id/y3zhj/epub/Schlesener-9788577982349.epub.

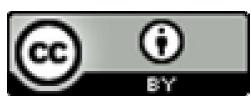

All the contents of this work, except where otherwise noted, is licensed under a Creative Commons Attribution 4.0 International license.

Todo o conteúdo deste trabalho, exceto quando houver ressalva, é publicado sob a licença Creative Commons Atribição 4.0.

Todo el contenido de esta obra, excepto donde se indique lo contrario, está bajo licencia de la licencia Creative Commons Reconocimento 4.0 . 


\section{CAPÍTULO III \\ A linguagem em seu contexto histórico E POLÍTICO ${ }^{1}$}

O escrito é como uma cidade, para a qual as palavras são como mil portas (BENJAMIN, 2009).

A pergunta sobre a linguagem e a sua colocação como paradigma no contexto da filosofia contemporânea nos move a outras interrogações: por que a valorização da dimensão simbólica e cultural no momento em que a sociedade se afirma cada vez mais no movimento de produção e consumo globalizados? É apenas o simbólico que nos diferencia das demais espécies de animais, ou as contradições implícitas em nossa vida social indicam a necessidade de outros parâmetros? $\mathrm{O}$ fato de concentrar-se em uma dimensão do humano sem considerar os elos sociais, políticos e culturais produzidos no contexto da sociedade moderna não seria um sintoma de uma opção política? O que pode ainda orientar a ação e a formação do homem numa sociedade na qual imperam objetivos estritamente mercantis e instrumentais? Como retomar a articulação das múltiplas determinações da vida humana num conhecimento que expresse o real em seu movimento num contexto que se fecha a leituras gerais e se fragmenta em especialidades também no campo da filosofia? Enfim, qual o significado político e pedagógico da linguagem nas suas várias formas de enunciação?

De uma perspectiva interdisciplinar, quando se fala em linguagem pensa-se imediatamente na oralidade como a forma de expressão por excelência. Entretanto, como acentua Pasolini (1995, p. 199), a "primeira e principal das linguagens humanas pode ser considerada a própria ação, enquanto relação de representação reciproca com os outros homens e com a realidade física".

E nessa senda, a imagem, a música, a poesia, o teatro, o cinema, a arte em geral e todas as manifestações simbólicas geradas a partir do

1 Parte do conteúdo deste capítulo foi retomado de: SCHLESENER, A. H. A linguagem e seu significado político e pedagógico a partir dos escritos de Gramsci. In: GOMES, V. C., SOUSA, J. R. e RABELO, J. J. (Orgs.). Gramsci, educação e luta de classes. Fortaleza: Imprensa Universitária, 2015a. 
desenvolvimento da imprensa e das demais tecnologias de comunicação constituem-se linguagem. Ou seja, ainda nas palavras de Pasolini (1995, p. 199), é como se o agir portasse em si um tipo especial de irracionalismo, um dado que se impõe no mundo moderno; trata-se de uma grande "violência exercida sobre nós por uma sociedade que, assumindo a técnica em sua filosofia, tende a tornar-se sempre mais rigidamente pragmática e a identificar as palavras com as coisas e as ações”, ocorrendo um fenômeno de desapropriação da palavra em favor de elites que controlam as línguas-guias.

Esse tema nos interessa porque se depreende de algumas leituras de filólogos, que a linguagem vem abordada prevalentemente como teoria linguística, sem a dimensão política que perpassa todo o pensamento de Gramsci. Curiosamente, nosso primeiro artigo sobre os escritos de Gramsci, publicado em 1983, tinha como objetivo salientar a dimensão política e ideológica da linguagem, de uma forma ainda introdutória por ser resultado de uma primeira abordagem.

A questão da linguagem, nos Cadernos do Cárcere, vem sempre relacionada com a cultura e a filosofia, sendo que todas as abordagens tem como pano de fundo as relações de poder; isso se torna possível a partir da crítica marxiana ao pensamento hegeliano, mostrando que a atividade filosófica precisa mudar de objeto e de perspectiva: o objeto da filosofia deixa de ser a busca do fundamento universal para fixar-se na realidade efetiva e concreta, a fim de explicitar o processo contraditório de formação da sociedade; por isso, a filosofia da praxis precisa efetuar uma crítica da linguagem na sua dimensão ideológica.

As classes dominantes, em cada momento histórico, se apropriam do passado cultural para consolidar seu poder e essa apropriação passa pelo domínio da linguagem. A necessidade dessa crítica em seus efeitos políticos exige a explicitação e aprofundamento do conceito de hegemonia enquanto dominação sedimentada pela formação continuada do consenso, que se consolida por meio da difusão de um pensamento homogêneo, que acaba por relegar as classes trabalhadoras a uma situação de subalternidade e submissão. Essa questão se torna fundamental no enfrentamento político, visto que a fragilidade dos vencidos também se sedimenta no fato que não possuem clareza de sua própria história e dos motivos de seus fracassos, porque não possuem uma narrativa organizada que evidencie suas lutas e interesses de classe; a história que conhecem e que tomam como verdadeira é sempre a história da perspectiva dos vencedores. 
Cabe aqui esclarecer os significados que Gramsci atribui a esses conceitos: a filosofia, para nosso autor, possui uma dimensão essencialmente política, ou seja, "deve tornar-se política para continuar a ser verdadeira, para continuar a ser filosofia” (Q. 11, p. 1472). A base dessa afirmação se encontra no Caderno 11, \& 12, que apresenta os pressupostos para a dimensão política da filosofia: que "todos os homens são 'filósofos'[...]”, vivendo no cotidiano, ainda que inconscientemente, conforme uma filosofia contida "na própria linguagem enquanto um conjunto de noções e conceitos determinados e não somente de palavras gramaticalmente vazias de conteúdo", no senso comum e na religião popular (Q. 11, p. 1375).

A política precisa ser entendida em seu sentido amplo, ou seja, a partir do modo como se estruturam as formas materiais de existência na sociedade capitalista e a sua expressão no modo de ser da sociedade; a nossa inserção no contexto da estrutura define o caráter político de nossa ação, visto que precisamos permanentemente nos posicionar no âmbito das lutas de classes. Estas, por sua vez, enraízam-se no modo de produção material e se reproduzem a partir das múltiplas articulações que compõem as formas de vida em geral. Enfim, a cultura assume significado e importância na medida em que as relações políticas se constroem fundadas na ideologia como prática de poder, ou seja, tanto filosofia quanto cultura tem como ponto de inflexão a centralidade da política. Na sociedade capitalista as relações de poder se constroem como dominação econômica que se sustenta e se consolida pela direção intelectual e moral a partir da formação do homem e de sua conformação aos interesses do trabalho.

A direção intelectual e moral apresenta-se como uma das principais condições, tanto para a conquista quanto para o exercício do poder, constituindo-se no elemento que materializa a dominação e a subalternidade por meio da formação do modo de vida. A divisão do trabalho que caracteriza o cotidiano nas relações sociais em geral (patrão-empregado, professor-aluno, dirigentes-dirigidos, governantes-governados) garante o equilíbrio das relações de forças entre as classes que se formam no contexto da produção e do consumo. Essas relações são naturalizadas e interiorizadas no processo educativo. Nesse contexto, a dimensão simbólica adquire significado político e a linguagem materializa as relações de poder consolidadas e interiorizadas pelas classes ou grupos sociais que interagem entre si.

A apropriação de uma linguagem (ou de uma concepção de mundo) assume importância fundamental no contexto das relações de poder capitalistas, na medida em que a hegemonia se sustenta pela divulgação e 
consolidação de um pensamento homogêneo. Expressar-se de modo claro e autônomo implica formalizar de modo orgânico as ideias e valores implícitos na ação e gerar as condições de um pensamento inovador assume uma força política inusitada no momento em que o conhecimento se transforma em instrumento de poder e dominação. Consolidar um pensamento hegemônico significa tolher das classes trabalhadoras a sua fala inovadora e torná-las reprodutoras do instituído e consolidado. Daí a importância da linguagem, tratada não apenas como lógica ou teoria que determina a ação, mas, ao contrário, como a expressão de um modo de ser e agir que se transforma no processo histórico e que, por sua vez, repercute na estrutura lógica de uma língua.

A crítica da linguagem se torna, assim, uma questão política fundamental para as classes trabalhadoras na medida em que a ideologia toma novas dimensões com o desenvolvimento dos meios de comunicação de massa, que se tornam mecanismos educativos cujo poder se encontra em divulgar uma ideologia como se fosse a verdade universal e não a expressão de interesses de classe, tolhendo a subjetividade do trabalhador que, ao assimilar o modo de pensar e o modo de vida dominantes, perde a sua autonomia política de organização.

\section{Breves observações sobre a questão da linguagem em Marx:}

As modificações das estruturas sociais, com as suas consequências culturais, etc., são a linguagem com a qual se expressam os revolucionários. Lenin, de certo modo, deixou escrito um grande poema de ação (PASOLINI, 1995, p. 200).

As bases de Gramsci para a crítica da linguagem se encontram em Marx, do qual retomamos alguns escritos para salientar que a dimensão simbólica, principalmente na linguagem oral, constrói-se como uma das dimensões da vida econômica, social e política, na forma de consciência ideológica. Trata-se de uma breve exposição, a fim de delimitar o contexto a partir do qual a linguagem se apresenta como a expressão empírica das formas de dominação hegemônica e ideológica explicitadas por Gramsci.

Partimos do seguinte ponto: a diferença de fundo entre Marx e o idealismo hegeliano se encontra principalmente no entendimento do homem a partir de sua historicidade, ou seja, a história não consiste no devir e na realização do logos, mas sim no movimento de produção e reprodução da vida pela mediação do trabalho. Pode-se argumentar que existem outros 
animais que trabalham e, portanto, o trabalho não pode consistir na diferença pela qual o homem se distingue e constrói a sua essência humana. No contexto da história da filosofia, já Aristóteles reconhecia que a diferença entre o homem, as abelhas e as formigas é que o trabalho humano é criador e transformador da natureza e do próprio homem.

Pela mediação do trabalho enquanto atividade material concreta, determinada pelas circunstâncias históricas, o homem cria as suas condições de viver e com elas o seu modo de ser, ou seja, ao renovar cotidianamente a própria vida, cria laços familiares, relações sociais, políticas e culturais, formando, nesse movimento, a sua subjetividade. Em outras palavras, os homens precisam produzir os meios de subsistência ou de sobrevivência antes de "fazer história" ou interpretar o mundo (MARX, ENGELS, 1976). O "agente histórico não é o homem que pensa e fala, mas aquele que produz e reproduz as condições de sua existência sensível”; não é o intelectual, mas o homem que "maneja o arado, o chicote ou a espada, que troca os produtos de sua atividade ou que vende a força de seu trabalho" (CHATELET, 1972, p. 227).

O leitor de Marx conhece as premissas das quais o autor parte e que são assinaladas em A Ideologia Alemã: a empiria, ou seja, os indivíduos e suas condições materiais de existência, são "bases verificáveis por vias puramente empíricas". E se acrescenta no texto: "pode-se referir a consciência, a religião e tudo o que se quiser como distinção entre os homens e os animais; porém, esta distinção só começa a existir quando os homens iniciam a produção dos seus meios de vida”, vale dizer, sua vida material (MARX, ENGELS, 1976, p. 18-19).

Trata-se de substituir a noção metafisica de uma essência humana a priori, que sempre encantou (e continua encantando) os filósofos e que culminou no idealismo hegeliano (que, embora reconhecendo a historicidade da sociedade, manteve as bases legitimadoras do discurso metafisico na ideia do Espirito Absoluto) por uma abordagem do movimento histórico no qual o homem, "em sua atividade sensível, forja sua própria realidade" e a interpreta (CHATELET, 1972, p. 227). Ou seja, indivíduos historicamente situados, com uma atividade produtiva determinada, que entram em relações sociais e políticas determinadas, a partir das quais conhecem a si mesmos e aos outros elaborando a sua interpretação da realidade.

A chave de leitura da realidade (ou paradigma de Marx, se a base de leitura de Marx for o pensamento chamado “pós-metafísico”) é o modo de 
produção e, nos seus desdobramentos, a consequente luta de classes e não a linguagem. A materialidade que caracteriza a produção da vida é condição para a produção do conhecimento e não o contrário; o próprio Marx explicita que é a divisão social do trabalho que, ao separar trabalho manual de trabalho intelectual, possibilita a ilusão de que o pensamento tem prioridade sobre o material e manual. O objetivo da filosofia em Marx deixa de ser a busca do fundamento universal para voltar-se para a realidade efetiva e concreta, o processo contraditório de formação e construção das sociedades. E não se trata de mostrar o que veio antes ou depois, o trabalho ou a linguagem, numa leitura dualista que descaracteriza o pensamento marxiano, mas de acentuar a relação dialética entre ação e pensamento, que foram separados de modo dualista a partir da divisão social do trabalho.

A inversão radical proposta por Marx em relação à filosofia alemã fica explicita: "não se parte daquilo que os homens dizem, imaginam e pensam nem daquilo que são nas palavras, no pensamento, na imaginação e na representação de outrem", mas parte-se dos homens em carne e osso, na "sua atividade real” (MARX, ENGELS, 1976, p. 26). A partir desses pressupostos e dessa inversão de abordagem, pela realização da dialética levando-a a suas últimas consequências, é que a questão da linguagem se coloca.

A linguagem é tão velha quanto a consciência: é a consciência real, prática, que existe também para outros homens e que, portanto, existe igualmente só para mim e, tal como a consciência, só surge com a necessidade, as exigências dos contatos com os outros homens. [...] A consciência é pois um produto social e continuará a sê-lo enquanto houver homens (MARX, ENGELS, 1976, p. 36).

Importante salientar que a frase cortada do manuscrito acentua que a consciência é relação com tudo o que nos rodeia. Ou seja, sendo relação, a consciência está também condicionada pela forma de sociedade da qual se faz parte, pelas circunstâncias sociais geradas a partir das relações de trabalho. Vale dizer que todo conhecimento é historicamente produzido, não é neutro, mas traduz relações de poder que se produzem no âmbito das lutas de classes. Isso nos remete a um outro texto de Marx no qual a questão da linguagem reaparece, sempre determinada pelas circunstancias históricas: O 18 Brumário de Luiz Bonaparte.

Os homens fazem a sua própria história, mas não a fazem como querem; não a fazem sob circunstâncias de sua escolha e sim sob aquelas com que se defrontam diretamente legadas e transmitidas pelo passado. A tradição de todas as gerações mortas oprime como um pesadelo o cérebro dos vivos. E justamente quando parecem empenhados em revolucionar-se a si e às 
coisas, em criar algo que jamais existiu, precisamente nesses períodos de crise revolucionária, os homens conjuram ansiosamente em seu auxílio os espíritos do passado, tomando-lhes emprestado os nomes, os gritos de guerra, as roupagens, a fim de se apresentar nessa linguagem emprestada (MARX, 1977, p. 17-18).

Entre outros elementos importantes, essa citação de Marx frisa o conteúdo ideológico da linguagem, ou seja, consciente ou inconscientemente a linguagem, enquanto expressão do real, também o mistifica. A linguagem e a interpretação formam o imaginário social que se realimenta do passado para explicar e sustentar as lutas do presente. A rememoração dos atos heróicos do passado serve tanto para impulsionar a ação transformadora do presente quanto para ocultar os limites e as contradições do projeto que se pretende implementar (MARX, 1977). Como pano de fundo do uso da linguagem e da história, a luta de classes, na correlação de forças entre o novo que quer nascer e o velho que não quer morrer, nas figuras de uma classe emergente que aspira ao poder e conjura em seu favor as vitórias do passado, outra que perde seu domínio e tenta manter-se no poder e, para isso, ressuscita os momentos privilegiados de seu passado. A linguagem torna-se aqui um instrumento político da maior grandeza, com outras conotações frisadas por Marx:

De maneira idêntica, o principiante que aprende um novo idioma, traduz sempre as palavras deste idioma para sua língua natal; mas só quando puder manejá-lo sem apelar para o passado e esquecer sua própria língua no emprego da nova, terá assimilado o espirito desta última e poderá produzir livremente nela (MARX, 1977, p. 18).

A aprendizagem de uma nova linguagem, que supõe o esquecimento do idioma de origem, tem como pressuposto a formação cultural e os elos que ligam os subalternos ao horizonte ideológico de seu tempo a partir dos laços de submissão que foram construídos historicamente. O conteúdo ideológico que se sedimenta na linguagem e dificulta a assimilação do novo ou mesmo a sua proposição, implícito nessa citação de Marx, nos remete ao pensamento de Gramsci sobre as relações de hegemonia que se consolidam e se perpetuam na formação do senso comum e na incapacidade dos subalternos de formular um pensamento inovador, que expresse realmente o conteúdo de suas lutas.

Ou seja, Gramsci interpreta e renova a questão da linguagem a partir da explicitação das novas formas de dominação que se ampliam com a inserção das novas tecnologias de produção e de comunicação de massa. Gramsci 
parte da crítica ao pragmatismo (que poderia ser estendido ao campo da filosofia analítica) e procura mostrar que a política alia-se cada vez mais à cultura para consolidar as relações de poder, de modo que as lutas de classes assumem uma nova dimensão que passa pela necessidade de um trabalho educativo-formativo das classes trabalhadoras, a fim de criar sua própria interpretação do mundo e, com isso, a sua identidade de classe. Para tanto, um dos caminhos é valorizar a sua linguagem, expressão de sua vida e de suas lutas; outro caminho vinculado ao anterior é aprender a traduzir para superar os limites do senso comum e de um pensamento homogêneo que sustenta a hegemonia burguesa.

A questão a ser enfrentada em se tratando da linguagem é mostrar que, na história, o controle da palavra sempre pertenceu aos dominantes e na sociedade moderna, mais do que nunca, esse poder se multiplicou com a inserção das novas tecnologias de comunicação; de modo que as classes trabalhadoras, para vencer as lutas políticas, precisam se reconhecer no movimento contraditório de construção da sociedade e, para isso, necessitam dominar a linguagem para enfrentar o dominador no seu terreno. Nesse contexto, o pressuposto para refletir sobre a questão da linguagem é a luta pela hegemonia, a qual implica necessariamente fazer a leitura da história, a fim de identificar-se como classe e apresentar-se como projeto político e social alternativo.

Os dois conceitos, hegemonia e linguagem, por sua vez, embasam o significado pedagógico que permeia a política e se organiza a partir da luta de classes. Pensar a educação, em particular a educação escolar, implica entender os mecanismos de elaboração das políticas públicas e os interesses que essas escondem no âmbito da luta de classes; a partir desse pressuposto, salientar a importância, para as classes trabalhadoras, do ensino escolar, principalmente porque por meio da escola se tem acesso ao domínio dos códigos de comunicação necessários para a formação de um pensamento coerente e como instrumento de contestação do poder instituído.

\section{"Esta mesa redonda é quadrada": a questão da gramática}

Abandonei a ideia de escrever (por força maior, dado a impossibilidade de conseguir o material necessário) uma dissertação com o título: "Esta mesa redonda é quadrada" que, penso, tornar-se-ia um modelo para os trabalhos intelectuais carcerários presentes e futuros (GRAMSCI, 1975d, p. 157) 
Gramsci foi um estudioso de linguística e poderia ter se tornado professor e pesquisador, não fosse a sua paixão pela política. ${ }^{2}$ Os Cadernos do Cárcere nos contemplam com vários fragmentos sobre os temas da linguagem e da gramática. A questão lógica que tomamos como título desse capítulo faz parte do \& 1 do Caderno 29 (escrito em 1935), retomando o $15^{\circ}$. ponto de pesquisa anotado no Caderno 1 em fevereiro de 1929: Neogramáticos e neolinguístas ("esta mesa redonda é quadrada"). O tema envolve a questão: “o que é a gramática?” ou: qual a relação entre a estrutura lógica do pensamento e o modo de vida ou a atividade concreta?

A crítica gramsciana da linguagem no seu confronto com a lógica e o pragmatismo, na vertente de Giovanni Vailati, mostra os limites da gramática se ela for abordada apenas no contexto do significado abstrato das palavras. Gramsci defende a dimensão política da linguagem e seu caráter metafórico, a partir do qual reflete sobre as possibilidades de tradutibilidade das línguas e sua dimensão ideológica, questão que assume atualidade a partir da nova dimensão no contexto da chamada "sociedade do conhecimento" e da comunicação, onde as novas tecnologias fortalecem os mecanismos de dominação política e econômica da sociedade capitalista.

Inicia-se com uma clara crítica a um ensaio de Benedetto Croce no qual o autor parte do estatuto gramatical da palavra para mostrar que sua estrutura lógica deve valer também para a estética. Se uma proposição não é lógica não pode ser pensada nem imaginada e, portanto, não tem sentido. Conforme Croce, é a definição gramatical da palavra que determina o seu uso.

Para Gramsci, ao contrário, o estatuto gramatical de uma palavra se estabelece a partir do contexto histórico (e político, como veremos adiante) e das necessidades de comunicação dos falantes, de modo que uma "proposição, ainda que não 'tecnicamente' gramatical”, possui uma função "expressiva e justificada”, mesmo que negativa ou contraditória. Os chamados "erros gramaticais" resultam basicamente de uma "ausência de disciplina mental, neolalismo, particularismo provincial, jargão, etc.”, ou seja, de uma falta de

2 Conforme Lo Piparo (2014, p. 160), Gramsci era conhecido nos meios científicos por sua dedicação ao estudo da filologia e glotologia; por ocasião de sua prisão publicou-se na Revista "Weltbuhne" informações sobre o processo de Roma, cujo acusado era "um dos mais importantes teóricos do movimento operário, de apenas 36 anos e bem conhecido no inteiro mundo cientifico [...] em 1919 foi convidado para uma cadeira na Universidade de Hamburgo, que recusou para não renunciar ao seu compromisso político". Os biógrafos de Gramsci não deram importância a esta notícia. Embora estejamos salientando esta observação de Lo Piparo, acentuamos que discordamos de sua leitura de Gramsci no livro citado, na medida em que encontramos vários equívocos quanto ao que se refere ao conceito gramsciano de linguagem. Essa questão é controversa. 
coerência lógica que pode decorrer de uma concepção de mundo fragmentada e assimilada sem critério, a partir da vivência cotidiana (Q. 29, p. 2341).

Portanto, a linguagem pode expressar contradições (até porque a realidade é contraditória) e a partir de um conjunto de articulações é que ela pode ser entendida:

a) na sua relação com a estrutura da sociedade, na qual o simbólico se efetiva como expressão dessa mesma estrutura; a linguagem não é a essência que distingue o homem dos animais, mas os homens se produzem e se conhecem pela mediação do trabalho, fonte criadora da sociedade e do pensamento, cuja expressão se faz pela linguagem;

b) a linguagem é metafórica e, como tal, traduzível ou vinculada ao principio da conversibilidade, viabilizando a relação dos saberes entre si e destes com o real vivido. O uso de metáforas auxilia a esclarecer o significado de conceitos, na medida em que ele (o uso) se relaciona "ao mundo cultural, historicamente determinado, do qual surgiu", assim como se deve limitar historicamente a própria metáfora, a fim de impedir que se torne um instrumento mecânico de explicação. Dessa perspectiva, cabe "distinguir entre os dois fundadores da filosofia da praxis, cuja linguagem não tem a mesma origem cultural" de modo que suas metáforas "refletem interesses diversos" (Q. 11, p. 1474).

c) A partir desse contexto, qualquer expressão linguística tem seu conteúdo ideológico e seus efeitos políticos. Os significados se renovam a partir da relação histórica que se instaura entre uma comunidade e seu passado cultural. Daí a importância dos intelectuais no contexto de produção e reprodução das relações de dominação e a necessidade de tirar todas as consequências da afirmação de que "todos os homens são intelectuais" (Q. 13, p. 1516).

Desse modo, o problema não pode ser formulado a partir da lógica ${ }^{3}$, mas sim "nos termos de 'disciplina em relação à historicidade da língua'[...]”, a partir da qual se abordam os "erros gramaticais". Ou seja, "tudo o que (não) é 'gramaticalmente exato' pode ser justificado", tanto do ponto de vista lógico quanto estético ou histórico, se entendido não apenas da perspectiva de uma "lógica particular, de expressão imediatamente mecânica,

3 A propósito dos limites de uma abordagem abstrata, Gramsci tem uma anotação sobre o raciocinar pela média estatística e como esta forma de raciocínio pode deformar o conhecimento da realidade. "Neste caso é útil recordar a piada segundo a qual um Fulano faz duas refeições ao dia e Beltrano nenhuma; 'estatisticamente' Fulano e Beltrano fazem 'em média' uma refeição ao dia cada um. A deformação do pensamento originada pela estatística é muito mais difundida do que se acredita. Generalização abstrata, tem uma retomada continua do contato com a realidade (Q. 26, p. 2298). 
mas como elemento de uma representação mais vasta e compreensiva". A gramática é histórica, é "a 'fotografia' de uma determinada fase de uma língua nacional (coletiva), historicamente formada e em desenvolvimento contínuo". A questão central é política, ou seja, qual a função prática dessa fotografia: "fazer a história de um aspecto da civilização ou modificar um aspecto da civilização?" (Q. 29, p. 2341). Em outras palavras: conservar relações de hegemonia ou transformar a ordem vigente?

Esta nota que abre o Caderno 29, dedicado ao estudo da gramática, pode se explicitar quando se considera que a linguagem, assim como o senso comum, expressa elementos de uma concepção de mundo desarticulada, fruto de uma ação não acompanhada de uma teoria clara, compostos a partir da assimilação de informações desarticuladas e absorvidas sem crítica; tais elementos, mesmo quando não diretamente vinculados aos interesses políticos das classes dominantes, apresentam uma característica conservadora e estática porque são naturalizados, atuando para a aceitação do dado e a passividade ante o estabelecido.

Por outro lado, embora assimilem elementos desagregados e muitas vezes contraditórios em relação ao viver cotidiano, as classes subalternas possuem elementos embrionários que possibilitariam a formação de uma concepção própria de mundo, que poderiam assumir uma organicidade a partir de sua organização política.

Para efetuar a crítica da linguagem e demonstrar que o modo de pensar "não é independente e autônomo, mas submisso e subordinado", é necessário evidenciar a historicidade dos fatos e esclarecer os elos da ideologia com a infraestrutura. As ideias se radicam na estrutura da sociedade e, desse modo, apresentam dinamicidade e organicidade, atuando para conservar ou transformar o instituído. Importante salientar que, na medida em que se assume uma concepção de mundo emprestada, perde-se a voz e a autonomia de agir e de criar, de expressar as inovações da própria prática, de elevar esta prática ao mais alto nível de expressão teórica.

A linguagem, como o senso comum, difunde uma ideologia unificadora, que não mostra suas raízes históricas e de classe. Por isso, uma unidade política e cultural exige uma critica da linguagem e Gramsci se esmera nesse trabalho, enfrentando as teorias positivistas, pragmáticas, principalmente as ideias de Giovanni Vailati, seguidor de Peano e simpatizante de Russel e de Pierce, em torno da teoria do significado ${ }^{4}$. Enfrenta os defensores da tam-se de teorias filosóficas desde os antigos até os modernos, o que lhes garante uma certa ambiguidade, 
lógica abstrata, mostrando que a linguagem não é fixa nem imutável, mas histórica e metafórica, retirando seus significados do movimento da vida.

Creio poder dizer que a concepção de linguagem de Vailati e de outros pragmáticos não seja aceitável: entretanto, parece-me que eles perceberam as exigências reais e as "descreveram" com exatidão aproximativa, mesmo não conseguindo colocar os problemas e encontrar as soluções. Parece que se possa dizer que "linguagem" é essencialmente um nome coletivo, que não pressupõe uma coisa "única" nem no tempo nem no espaço. Linguagem significa também cultura e filosofia (ainda que a nível do senso comum) e, portanto, o fato "linguagem" é, na realidade, uma multiplicidade de fatos mais ou menos organicamente coerentes e coordenados: no limite se pode dizer que cada ser falante tem uma linguagem própria, ou seja, um modo próprio de pensar e de sentir (Q. 10, p. 1330).

A cultura unifica essas linguagens individuais em diversos graus, permitindo a comunicação ou o contato expressivo, ou seja, a "causa dos erros" não se encontra nas palavras, como querem os pragmáticos, mas no conteúdo ideológico que elas veiculam, na multiplicidade de sentidos que apresentam a partir das diferenças histórico-sociais, expressos nas diversidades culturais ${ }^{5}$. Os pragmáticos, e mais diretamente Pareto, procuram teoricamente as "causas de erro" na aplicação das palavras, como se a linguagem fosse estática quando, na verdade, ela se transforma no movimento de transformação da civilização e da cultura. A "linguagem é sempre metafórica”, principalmente em relação ao seu conteúdo ideológico construído ao longo da história; "toda a linguagem é um contínuo processo de metáforas, sendo a história da semântica um aspecto da história da cultura: a linguagem é um conjunto de coisas vivas e um museu de fósseis da vida e das civilizações passadas” (Q. 11, p. 1438).

Em linhas gerais, a questão da linguagem nos remete aos temas da cultura e da filosofia que, por sua vez, só podem se explicitar se enraizados na política. A linguagem se transforma no movimento histórico, com o surgimento de novas classes sociais e novas culturas. A linguagem pode não ser metafórica em relação ao objeto material que nomina, mas seguramente é

expressa em ensaios sobre temas ligados à questão da linguagem. Pode-se citar Pierce, mas também James e chegar a Dewey.

5 Assim como fez na crítica ao esperanto, no Caderno 3, a propósito de Lorianismo, Gramsci retoma a crítica de Pisani à teoria da monogênese de Trombetti, acentuando que a língua não se reduz ao puro léxico e que as palavras em línguas diferentes, mesmo com grafia igual, não apresentam o mesmo significado. As "formas lexicais e seus significados devem ser cotejados por fases históricas homogêneas das línguas em questão" e que, para cada forma, "é necessário 'fazer', além da história fonológica, a história semântica para cotejar com os significados mais antigos". O "parentesco de duas línguas não pode ser demonstrado pela comparação" de palavras, se faltam os argumentos gramaticais fonéticos, morfológicos e sintáticos (Q. 3, p. 408-9). 
metafórica em relação aos significados e conteúdos ideológicos que expressou em épocas anteriores; por isso, as palavras não podem ser abordadas como estáticas e verdadeiras de uma vez por todas, mas precisam ser entendidas dentro de um contexto crítico e histórico (Q. 11, p. 1438-1439).

Essa questão está presente já no Caderno 1, parágrafo 92, a propósito do americanismo, cuja força está em que "é uma filosofia que se afirma na ação", que modifica a realidade externa, ao contrário de outras filosofias que modificam apenas o "vocabulário e não as coisas" (Q. 1, p. 91). Essas "outras filosofias" possivelmente sejam o pragmatismo europeu, que difere basicamente do norte-americano na medida em que este se traduz em modo de vida, que modifica internamente o homem e a sociedade, enquanto o pragmatismo europeu, fruto de uma cultura arraigada na tradição elitista, não atinge a sociedade como um todo.

Essa questão é atual na medida em que uma das bases do chamado pós-modernismo se encontra na exaltação das estruturas da linguagem como constitutivas da essência humana, determinando as regras que orientam tanto a vida social e cultural quanto a identidade dos sujeitos. É certo que Gramsci não ignora essa dimensão da língua, mas reformula a proposição acentuando a sua historicidade e a sua importância no contexto das lutas de classes, retirando a linguagem de seu limbo metafísico para acentuar a sua dimensão política, ou seja, o modo como a linguagem se transforma em instrumento de poder no contexto das relações de hegemonia.

A luta de classes e a organização política dos trabalhadores se apresenta, para Gramsci, entre outros fatores, na necessidade de criticar o pragmatismo e seus efeitos políticos, desvelando o conteúdo ideológico de toda linguagem. A reflexão não se limita a discutir paradigmas, mas transita nos limites entre "filosófico" e "não-filosófico" para mostrar a importância de embasar a luta política na formação cultural, a fim de gerar as condições aos que "não sabem" de romper os elos da dominação e retomar a voz e a palavra elaborando o seu próprio pensamento.

Em termos práticos, essa questão se explicita na elaboração das políticas públicas para a educação e na possibilidade de acesso aos códigos de leitura e interpretação; por exemplo, ainda no Caderno 29, Gramsci pergunta quantas formas de gramática podem existir e reponde: muitas, pois toda forma expressiva traz implícita uma gramática que, em geral, não é considerada pelos neopragmáticos e os neolinguístas. A questão política é que as “manifestações 'espontâneas' de um conformismo gramatical” (na 
língua falada) é "desconexo, descontínuo, limitado a estratos sociais locais" (Q. 29, p. 2342-2343); a importância de uma gramática normativa escrita e ensinada na escola está no fato de ela possibilitar unificar as formas expressivas e abrir a possibilidade de uma crítica ao modo de pensar fragmentado.

O estudo da "gramática normativa escrita é sempre uma 'escolha', uma orientação cultural, ou seja, é sempre um ato de política cultural-nacional”. Em linhas gerais, depende das relações de hegemonia, da divisão social em classes e da separação entre dirigentes e dirigidos (Q. 29, p. 2344). Neste contexto, quem se propõe escrever uma gramática precisa ter clareza de sua "escolha", buscando "o centro de irradiação espontânea das inovações linguísticas”, inserindo-as de forma relativamente orgânica (Q. 29, p. 2344-2345).

Gramsci salienta os principais focos de irradiação das inovações linguísticas a serem considerados por quem escreve uma gramática: entre eles, a escola, os jornais, os escritores de arte e os populares, o teatro, o cinema, o rádio, as reuniões em geral, os relatos de experiências, as canções populares, etc., todos os elementos necessários para elaborar uma gramática histórica e/ou normativa enquanto expressão de uma língua unificada (Q. 29, p. 2345).

Para a formação dos trabalhadores, a gramática normativa escrita ensinada nas escolas é, portanto, de suma importância, porque abre a possibilidade de conhecer a língua de forma mais sistemática e de, dominando os códigos formais, dominar as formas argumentativas para elaborar um pensamento coerente e articulado, a fim de formar a sua própria identidade de classe. A importância da educação escolar se vincula à necessidade de construir as bases de luta política, necessárias para a formação de uma nova concepção de mundo. No caso do estudo da gramática normativa, Gramsci a compara ao estudo do latim nas escolas clássicas:

A gramática normativa, que somente por abstração pode ser considerada separadamente da linguagem viva, visa a fazer com que se aprenda todo o organismo de uma determinada língua, assim como ajuda a criar uma atitude espiritual que torne capazes de se orientarem num ambiente linguístico (Q. 29, p. 2349).

Quando um governo, na sua política educacional, decide retirar do currículo essa gramática como aconteceu com a Reforma Gentile, em $1923^{6}$, retira das classes populares a possibilidade de ter o aprendizado da língua

6 Esse tema abordaremos no capítulo sobre a educação. Um tema candente que, embora se refira, em Gramsci, ao contexto do fascismo italiano, serve para refletir sobre as nossas políticas educacionais. 
culta e de formular um pensamento coerente, ou seja, de ter acesso à produção cultural e ao conhecimento historicamente produzido. Na atitude de Gentile "há muito mais política do que se acredita", há "o reacionarismo da velha concepção liberal, há um 'deixar fazer, deixar passar' que não é justificado" (Q. 29, p. 2349).

Nesse contexto de leitura a crítica da linguagem e de seus efeitos políticos se apresenta como um dos momentos de elaboração do conceito de hegemonia enquanto forma de dominação que se sustenta na direção intelectual e moral, ou seja, na constituição e manutenção de uma elite de intelectuais capaz de elaborar um consenso ou de alimentar o senso comum com fragmentos de culturas mesclados com informações pretensamente neutras a fim de incentivar a aceitação do dado, a naturalização da história, a passividade ante o estabelecido, contribuindo para a estabilidade da prática social.

Essa questão se apresenta no próprio modo de escrever dos intelectuais, mostrando que a literatura é sempre perpassada por posicionamentos políticos. Gramsci o explicita no Caderno 14, a propósito da literatura popular e a relação entre conteúdo e forma: "existe uma diferença de estilos entre os escritos dedicados ao público e os outros, por exemplo entre as cartas e as obras literárias. Frequentemente parece que estamos diante de dois escritores diversos, tamanha é a diferença”. Nos escritos dedicados a poucos "predomina a sobriedade, a simplicidade", enquanto "nos outros escritos predomina a presunção, o estilo oratório, a hipocrisia estilística". Esta “[...]'doença' se encontra tão difundida" que foi assimilada pelo povo, para o qual “escrever” significa “[...]'fingir' um estilo redundante”, ou seja, “exprimir-se de um modo diferente do comum”. Daí se pode concluir que em uma determinada linguagem, o “[...]'conteúdo' indica um determinado modo de pensar, não somente histórico, mas ‘sóbrio', expressivo” (Q. 14, p. 1738).

Explicitar as relações de hegemonia implica mostrar que a linguagem radica-se na estrutura da sociedade, tem raízes histórico-sociais e, portanto, é ideológica e funciona como instrumento de poder e de dominação. No dizer de Edmundo Fernandes Dias, "construir a hegemonia pelos dominantes implica na destruição das formas culturais” vivenciadas pelas classes populares, processo que vai muito "além da pura incorporação de palavras ou expressões anglófilas”; passa pelo "apagamento de linguagens culturais”, produzindo um "horizonte ideológico" unificado que fundamenta o modo de pensar das classes subalternas (DIAS, 2012, p. 144). 
A linguagem é, pela formação do senso comum e por meio da fragmentação do pensamento ou pela divulgação de elementos dispersos e parciais, um dos mecanismos que escondem as desigualdades sociais e culturais naturalizando os fatos; mas pode ser ainda instrumento importante para a obtenção de uma nova unidade cultural, a partir da organização política dos trabalhadores e da superação do silêncio ao qual são reduzidos a partir da assimilação de uma linguagem. Somente a organização política permite superar as limitações culturais impostas pela hegemonia dominante, a partir da explicitação das contradições que permeiam o social e da formação de uma concepção crítica e coerente (Q.10, p. 1330-1331).

A linguagem expressa ou esconde um projeto de hegemonia. E todo movimento social de luta por uma nova ordem "cria uma linguagem própria, ou seja, participa no desenvolvimento geral de uma determinada língua” na medida em que introduz "novos termos, enriquece com novo conteúdo termos já em uso, cria metáforas", recorre a nomes históricos para facilitar a compreensão de determinadas situações políticas (Q. 29, p. 2264-2465).

Os Cadernos do Cárcere são ricos em análises de situações históricas (Reforma e Renascimento; Revolução Francesa, Risorgimento e função dos Moderados e do Partido da Ação, entre outros), as quais servem como aprendizagem do encaminhamento das lutas, de como a hegemonia dominante se constrói, das formas de subalternidade que se consolidam. Daí a importância de superar as formas de analfabetismo e ampliar as possibilidades de formação dos trabalhadores, a importância da leitura dos clássicos da literatura, a necessidade de a Itália criar condições de formação de uma linguagem nacional-popular. É na medida em que um movimento político se organiza e envolve as massas criando condições de intervenção política que as palavras assumem novos sentidos, apontam novas direções e o pensamento esclarece o significado das práticas, permite uma visão de conjunto que evidencia as forças em presença e os encaminhamentos possíveis.

Elaborar a própria concepção de mundo significa reconhecer-se como classe, criar uma identidade de classe, assim como a consciência de si e dos objetivos a alcançar. "A compreensão de si mesmo, a luta entre o antigo e o novo, a luta pela hegemonia consiste (também) em se situar na linguagem, posto que a própria linguagem, através de um meio social, nos situa aí como sujeitos" (BUCI-GLUCKSMANN, 1980, p. 460). Essa questão é fundamental na luta pela hegemonia: a linguagem é o instrumento de unificação política e cultural de uma classe, bem como da formação de sujeitos 
autônomos que reconhecem os limites e possibilidades de sua ação. Com o desenvolvimento do capitalismo financeiro em âmbito internacional, com a inserção das novas tecnologias de produção e comunicação, a hegemonia e a luta de classes assumem uma nova dimensão que é cultural e simbólica, fortalecendo e sustentando as relações econômicas e suas novas formas de dominação e exploração da força de trabalho.

\section{A dimensão simbólica no contexto das lutas de classes}

Se o político é um historiador, o historiador é também um político $e$, neste sentido, a história é sempre história contemporânea $(Q$. $10, p .1242)$.

$\mathrm{O}$ fato de concentrar-se em uma dimensão do humano sem considerar os elos sociais, políticos e culturais produzidos no contexto da sociedade moderna a partir do modo como se organizam as relações de trabalho não seria um sintoma de uma opção política? Certamente, a valorização da linguagem como básica na formação da essência humana tem um significado político e ideológico que se esclarece apenas se tiver como pressuposto à estrutura da sociedade moderna fundada na divisão social do trabalho e na exploração da força de trabalho.

Trata-se de superar a visão dualista que separa pensamento de ação e que Gramsci aprofunda ao explicitar o significado de filosofia da praxis: no Caderno 10, Gramsci retoma uma expressão de Bacon quando diz que "o conhecimento é poder", na medida em que "o homem não entra em relações com a natureza pelo simples fato de ser ele natureza”, mas sim "por meio do trabalho e da técnica". Tais relações "são ativas e conscientes" e, por meio delas, "cada um transforma a si mesmo, se modifica, na medida em que transforma e modifica todo o conjunto de relações do qual se faz parte"; ter consciência dessas relações ou conhecer a realidade na qual se vive significa "conhecer mais ou menos o modo pelo qual (a realidade) pode se modificar” e esse processo de conhecimento "já as modifica. As próprias relações necessárias, na medida em que são conhecidas em sua necessidade, mudam de aspecto e de importância” (Q. 10, p. 1345). Para as classes subalternas o conhecimento se adquire no movimento de organização política pelo qual, na medida em que se age, se conhece e se altera a realidade na qual se está inserido.

A luta de classes supõe cada dia com mais intensidade a criação de uma autonomia intelectual das classes subalternas que implica o domínio 
da linguagem ou a elaboração de uma linguagem própria. No contexto da sociedade tecnológica e dos meios de comunicação de massa, o poder da linguagem transcende todos os antigos limites. Pier Paolo Pasolini, leitor de Gramsci e estudioso da linguagem, em artigo de 1968, ao ser perguntado por que os intelectuais, em geral, não colaboram com programas televisivos, alerta para o poder autoritário e incondicional da televisão: primeiro, porque "entre vídeo e expectador não há possibilidade de diálogo. O vídeo é uma cátedra" que "consagra, dá autoridade, oficialidade". Segundo, porque "o vídeo representa a opinião e a vontade de uma única fonte de informação, que é precisamente - de modo genérico - a do Poder. E, desse modo, mantém o expectador submisso". O que quer que se diga, entra em um universo de relações de poder e de informações centralizadas e manipuladas conforme os interesses da emissora e de quem a financia e não no interesse da informação efetiva. "Por essas razões", completa Pasolini, "é claro que um intelectual, teoricamente, só pode dizer 'não' à televisão” (PASOLINI, 1982, p. 97-98).

Essas observações feitas no final da década de 60 tomam dimensões inusitadas se pensarmos na mundialização $0^{7}$ do capital, na reforma neoliberal dos Estados e nas novas configurações da telemática no início do século XXI, com uma concentração mundial da propriedade privada dos meios de comunicação de massa nas mãos de poucas famílias. Os meios de comunicação em geral, cinema e televisão à frente, "realizam uma poderosa ação transformista, absolutamente necessária à Ordem, de conversão do desejo em necessidade" (DIAS, 2012, p. 145). Necessidades supérfluas que são apresentadas como meios de realização da felicidade formando o imaginário de uma sociedade carente que se alimenta do sonho de ascensão social para usufruir dos bens do sistema produtivo. Pasolini acentuava que a televisão "é o lugar onde se torna concreta uma mentalidade que de outro modo não acharia onde colocar-se. É através do espírito da televisão que se manifesta o espírito do novo poder" econômico e político, na forma mais “autoritária e repressiva” de formação do consenso (PASOLINI, 1979, p. 31-32).

Antonio Gramsci acentuava como um consenso passivo funciona no contexto da consolidação da hegemonia e já se preocupava com a atuação dos jornais na formação da opinião pública, determinando os caminhos de um

\footnotetext{
7 Retomando as reflexões de Lea Durante (2000/2001, p. 86), entende-se mundialização como a "atual fase de expansão transnacional da economia" que, em sua "dimensão ideológica", se traduz na "transferência dos poderes reais e da hegemonia dos Estados para as empresas. A partir desse esquema se estrutura uma série de corolários, como a positividade da divisão internacional do trabalho como fator de progresso para as áreas menos desenvolvidas, a esperança de um reconhecimento cada vez mais amplo dos direitos civis e assim por diante".
} 
processo eleitoral ou de uma política. Na luta pela hegemonia a linguagem é um instrumento de unificação de uma vontade nacional e esse trabalho é feito pelos intelectuais. A tendência a formar uma elite distante do povo dificulta, para as classes dominantes, manter a hegemonia. Em geral, com o desenvolvimento do capitalismo e com a subordinação dos agentes de comunicação às empresas que os empregam, resolveu-se em grande parte o problema. A produção de um mercado de consumo de cultura de massa (cinema, novelas, best-sellers, etc.) sedimenta a hegemonia a partir da formação de um pensamento homogêneo, que se traduz em comportamentos adequados aos objetivos da hegemonia. Gramsci o descrevia da seguinte forma:

Quando a concepção do mundo não é crítica e coerente, mas ocasional e desagregada, pertencemos simultaneamente a uma multiplicidade de homens-massa, nossa própria personalidade é composta de maneira bizarra: nela se encontram elementos dos homens das cavernas e princípios da ciência mais moderna e progressista; [...]. Criticar a própria concepção de mundo significa torná-la unitária e coerente e elevá-la até o ponto atingido pelo pensamento mundial mais desenvolvido (Q. 10, p. 1376).

Superar a fragmentação e as contradições da própria concepção do mundo e elaborar uma consciência crítica só pode ser efetuado em grupo, num movimento de organização política, com projetos sociais definidos, processo que passa pela ressignificação da linguagem e aprofundamento do conhecimento da língua nacional. Mesmo quando se assimila a concepção do mundo hegemônica, se possui uma "concepção própria do mundo, ainda que embrionária, que se manifesta na ação e, portanto, descontínua e ocasionalmente". Enquanto não se desvela o embrionário, fato que só pode ocorrer num movimento político organizado, o subalterno "toma emprestada a outro grupo social, por razões de submissão e de subordinação intelectual, uma concepção do mundo que lhe é estranha”, ou seja, que não expressa o seu cotidiano e seus interesses de grupo (Q. 10, p. 1379).

Essa questão torna-se fundamental, porque a fragilidade dos vencidos se determina pelo fato de que não possuem uma concepção do mundo bem elaborada, que expresse seus interesses e suas práticas de classe. Daí a importância da cultura e da educação, bem como da atuação dos intelectuais no contexto do pensamento de Gramsci.

Cabe acentuar que, embora os meios de comunicação de massa consolidem um pensamento homogêneo, um consenso total e cristalizado não existe e a sociedade, em qualquer momento histórico, a bem dizer, vive 
diferenças ideológicas e visões conflitantes da realidade, que tomam proporções de enfrentamento e de tensão profunda conforme os movimentos de organização política das classes subalternas. É nos momentos de crise econômica e política que as contradições emergem e os conflitos podem tomar proporções radicais, levando a situações em que um consenso se torna impossível.

Gramsci acentua que o que se apresenta na forma da língua ou da linguagem é a aparência sob a qual se escondem outros problemas de fundo, como a necessidade de "formação e ampliação da classe dirigente, a necessidade de estabelecer relações mais próximas e seguras entre os grupos dirigentes e a massa popular-nacional, ou seja, de reorganizar a hegemonia cultural" (Q. 29, p. 2346).

Um dos mecanismos de aprendizagem da língua que Gramsci considera essencialmente político é a gramática normativa, que precisa ser colocada em relação com a gramática histórica, que são distintas, mas que, como a política e a história, não podem ser pensadas separadamente:

Posto que a gramática normativa é um ato político e que somente partindo deste ponto de vista se pode justificar "cientificamente" a sua existência, que enorme trabalho de paciência requer a sua aprendizagem, (quanto trabalho se faz necessário para conseguir que centenas de milhares de jovens das mais diferentes origens e preparação mental se tornem um exército homogêneo e capaz de mover-se e agir disciplinada e simultaneamente: quantas 'lições práticas e teóricas' de regulamentos, etc.) deve-se perguntar de sua relação com a gramática histórica (Q. 29, p. 2347).

O estudo das línguas apresenta-se como um fenômeno cultural, enquanto formação que se faz na vida e não apenas na escola, passa pelo transformismo e pela negação ou apagamento das culturas das classes populares, que assimilam gradativamente o modo de ser e pensar hegemônicos veiculados pelos meios de comunicação de massa. Uma vez apagadas ou esquecidas, as culturas tradicionais e todos os seus ensinamentos, em geral fruto da memória dos mais velhos e da transmissão oral, perdem-se para sempre.

Pasolini acentua, em seus Escritos Corsários, que a cultura se constitui do conjunto de todas as culturas de classe, num texto que lembra o que Gramsci nos diz sobre a filosofia:

O que é a cultura de uma nação? Pensa-se geralmente, mesmo entre a gente culta, que é a cultura dos cientistas, dos políticos, dos professores, dos literatos, dos cineastas, etc., isto é, a cultura da intelligentsia. No 
entanto, isso não é verdade. E também não é a cultura da classe no Poder, que, justamente através da luta de classes, tenta impô-la pelo menos formalmente. Finalmente, também não é a cultura da classe oprimida, ou seja, a cultura popular dos operários e camponeses. A cultura de uma nação é o conjunto de todas estas culturas de classe: é a sua média. E seria, pois, abstrata se não fosse reconhecível - ou antes, visível - no vivido e no existencial, e se não tivesse por consequência uma dimensão prática (PASOLINI, 1979, p. 55 - grifo do autor).

Essa definição de cultura de Pasolini nos lembra as observações de Gramsci sobre a filosofia de uma época e, poderíamos ainda dizer, a linguagem de um tempo: não existe uma filosofia, mas filosofias e sempre se escolhe uma entre elas, assim como existem várias linguagens, num movimento contraditório de produção e reprodução do pensamento vinculado a determinadas práticas, as quais formam um modo de pensar e de sentir.

Essa diversidade, porém, com as novas tecnologias de comunicação, parece estar com os dias contados. Pasolini, já na década de 1970, alertava para um novo tipo de centralismo, que supera imensamente a proposta fascista consolidada na Itália, que se traduz na formação da sociedade de consumo como um novo fenômeno cultural que unifica a partir da veiculação da ideologia que sustenta a sociedade capitalista. A ideologia se apresenta na falsa imagem da tolerância e no conformismo que, no fundo, têm traços profundamente repressivos, no modo como os meios de comunicação de massa reduzem todos "ao normal e conformista como o consumidor"; os condicionamentos se produzem por uma postura pretensamente democrática, mas profundamente autoritária, como via de mão única que não possibilita diálogo ou confronto (PASOLINI, 1979, p. 56-57).

Essa ideologia se faz acompanhar pelo hedonismo, que esconde a "determinação de planear tudo com uma desumanidade tal como a história jamais tinha conhecido até agora”. Esse novo Poder tem expressão na formalização dos códigos de comunicação e na formação de um comportamento unificado, "num momento da história em que a linguagem verbal é completamente convencional e esterilizada (tecnicizada), a linguagem do comportamento (corporal e mímico) assume uma importância decisiva”. Escrito em 1974, o artigo parece prenunciar a formação de um pensamento único, a produzir-se pela atuação dos meios de comunicação de massa, que veiculam uma linguagem corporal acompanhada de uma linguagem verbal "completamente reduzida a convenções e extremamente pobre" (PASOLINI, 1979, p. 56-57). Assistir a qualquer programa da televisão brasileira quase cinco décadas depois confirma esse prognóstico. 
Raul Mordenti (2007, p. 18) vai mais longe ao explicitar a inversão realizada pelos meios de comunicação de massa, concretizando o que Marx descreve no primeiro livro de $O$ Capital como fetichismo da mercadoria: "um programa televisivo não é produzido para ser vendido ao público, mas sim produzido para vender o próprio público para as empresas publicitárias". Desse modo, o público, de sujeito passivo "do mecanismo de compra e venda, torna-se o seu objeto". Com efeito, "é precisamente a presença de uma tal mercadoria, o público, que determina sob a base dos índices de audiência os valores dos espaços publicitários que financiam os programas" e permitem a acumulação de enormes lucros dos proprietários das redes televisivas. "As consequências dessa inversão são politicamente decisivas".

Mordenti (2007, p. 18) acentua ainda que essa inversão tem um efeito deformante sobre o modo como se veicula o "sentido das coisas", sobre "a possibilidade dos homens e mulheres de pensar juntos e de trocar entre si experiências e saberes". Isso porque a "publicidade prescinde (e deve prescindir) da pretensa verdade das coisas", sendo essa a "modalidade dominante e absolutamente penetrante da cultura contemporânea", de modo que a "própria cultura sofre uma redução rigorosa à comunicação", sendo que esta "não comunica nada mais senão a si mesma" tornando-se o parâmetro da verdade. Vivemos uma época que suprime o sentido das coisas e cria seus próprios sentidos em função dos interesses do capital: a felicidade se resume em beber um refrigerante; os desejos e necessidades se reduzem a comprar o último celular em moda, etc.

Conforme Dias (2012, p. 145), a televisão tem, em geral, uma função "conservadora quando não abertamente reacionária. Seu mote é a despolitização ou a politização favorável aos dominantes”. O domínio econômico no contexto da globalização se firma e se consolida no domínio político e ideológico, concentrado na "fusão das potências midiáticas" (DIAS, 2012, p. 146). Nesse horizonte no qual se forma o imaginário do cidadão expectador dócil e passivo, a força da linguagem, verbal e imagética, reduz as classes populares a um saber superficial e fragmentado que constitui seu senso comum e destrói todas as suas possibilidades de resistência.

Os caminhos de transformação dessa realidade passam pela apropriação dos mecanismos de direção cultural, de formação intelectual e moral da sociedade, colocando em evidência a educação no contexto das relações de hegemonia. Se pensarmos nos altos índices de analfabetismo entre as classes populares em âmbito mundial e nas dificuldades de estabelecer a relação entre alfabetização e letramento, enquanto domínio efetivo dos 
mecanismos de conhecimento, podemos formar uma ideia da extensão do problema. Mais do que na aurora do capitalismo, quando da formulação de Bacon de que "o conhecimento é poder", essa assertiva se tornou real no capitalismo contemporâneo: fala-se muito em "sociedade do conhecimento" e nunca como nesse início de século houve uma concentração tão grande do conhecimento em poucas mãos, instrumento de domínio econômico, social e político, de manutenção das formas mais antigas de dominação e de consolidação de novas formas de subordinação que passam pela formação da subjetividade na assimilação de um pensamento homogêneo.

Nesse contexto é que se inserem os termos gramscianos "subalterno" e "subalternidade": subalterno é o indivíduo dominado, mesmo sem ter consciência disso porque vive em um contexto de extrema alienação. Essa alienação se institui, como afirmava Marx, a partir das relações de trabalho, estendendo-se ao conjunto das relações sociais e modos de vida; uma situação garantida pela veiculação de ideias como "democracia" que, na forma da alternância de grupos ou indivíduos no poder, ou seja, na sua ambiguidade, gera a crença de participação igual garantida pela lei. A formalidade da lei extensiva a todos dissolve ou esconde o antagonismo de classes fundado na desigualdade econômica e na exploração do trabalho, esconde a realidade na qual as desigualdades se aprofundam na medida da concentração do capital e da renovação permanente do capitalismo.

A subalternidade se produz tanto no contexto da exploração do trabalho já analisada por Marx em $O$ Capital, onde esclarece, entre outras coisas, como o contrato de trabalho fundado na ideia de "liberdade igual dos contratantes" oculta o processo de exploração que se instaura a partir da compra da força de trabalho, identificada no cotidiano numa experiência sui generis, no qual o comprador da força de trabalho, o capitalista, vai à frente, com seu ar altaneiro "sorriso velhaco e ávido de negócios”, enquanto o trabalhador o segue cabisbaixo, "tímido, contrafeito, como alguém que vendeu sua própria pele e apenas espera ser esfolado” (MARX, 1980, p. 197).

A subalternidade produzida a partir da estrutura do modo de produção capitalista estende-se a todas as outras instâncias da vida social e se consolida na contemporaneidade com o fortalecimento dos meios de comunicação de massa, na formação de um consenso passivo. A inversão que se caracteriza no modo como a forma mercadoria torna possível que uma "relação social definida, estabelecida entre os homens, assuma a forma fantasmagórica de uma relação entre coisas" e estende-se ao modo de pensar e de ser dos indivíduos (MARX,1980, p. 81). 
Vivemos uma época na qual, no dizer de Mordenti (2007, p. 18) ocorre "uma perfeita inversão do sentido das palavras e das coisas", ou ainda esclarecendo, de "supressão do sentido das coisas", gerando naqueles que se apercebem da situação, uma sensação de permanente absurdo. Essa confusão generalizada de posições, de sentidos, o esmaecimento de valores historicamente consolidados, a fragmentação do conhecimento, a valorização do especialista, as palavras que designam o aparente e cotidiano, tudo concorre para a consolidação das formas de subalternidade que se reproduzem em apatia política e inação, sem condições de, ao menos, indignar-se ante o que se veicula nos meios de comunicação.

A possibilidade de um projeto econômico e social alternativo, de uma democracia efetiva e não apenas formal, se encontra na capacidade das classes trabalhadoras de se organizarem e efetivarem a sua capacidade de luta, superando as condições de subalternidade existentes, entre elas as que se consolidam no sentido abstrato de determinadas palavras como "liberdade", democracia", "paz", etc ${ }^{8}$.

A palavra "liberdade", por exemplo, tomada no cotidiano na sua forma abstrata e mais comum de escolha entre determinadas opções, conforme a vontade individual e as características da natureza humana; nessa abordagem, ignora-se que essa liberdade é determinada pelas condições sociais e políticas que fundam a formação e a vida de cada indivíduo; ignora-se ainda um pressuposto fundamental da modernidade, que consiste em que a liberdade se define a partir da base jurídica que caracteriza o pensamento moderno, com o objetivo de garantir formalmente direitos subjetivos. Cabe explicitar que o formal não expressa o real, visto que este se constitui por uma situação de desigualdade historicamente instituída, com base na exploração da força de trabalho e sua consolidação na estrutura capitalista de produção.

O mesmo pode-se dizer de outras palavras tomadas no seu sentido imediato e cotidiano. Tomar as palavras em sua radicalidade significa fazer o traçado de sua história, o que implica, para as classes trabalhadoras,

8 Trata-se de uma inversão que obnubila a consciência das massas populares e enreda as classes subalternas na teia do direito instituído, que as leva a naufragar no reformismo. O direito, tomado como norma neutra e válida para todos os indivíduos indiscriminadamente dilui as características fundamentais da luta de classes. Como acentua Edelman (2016, p. 72) a "violência tornou-se uma relação jurídica, a luta de classes tornou-se um conflito de direitos e as próprias classes tornaram-se sujeitos de direito, cada uma por si própria, detentora de 'seu' direito. De um lado, o empregador é sujeito do direito de propriedade; de outro, os operários são sujeitos do direito do trabalho. Consequentemente, a relação capital/trabalho transformou-se numa relação jurídica entre direito de propriedade e direito de trabalho". Os pressupostos que sustentam o direito não são questionados. 
elaborar sua própria concepção de mundo, ou seja, um modo de pensar que coincida com o sentir, que permita entender, explicitar e superar as contradições vividas e fazer a crítica ao modo de pensar hegemônico. Implica afirmar sua identidade de classe, o que só é possível, na leitura de Gramsci, a partir de seu empenho na sua organização política.

\section{A linguagem como metáfora e a afirmação da identidade dos subalternos}

Toda a linguagem é um contínuo processo de metáforas, sendo a história da semântica um aspecto da história da cultura: a linguagem é, simultaneamente, uma coisa viva e um museu de fósseis da vida e das civilizações (Q. 11, p. 1438).

Retomamos agora o item b, que acentua que a linguagem é metafórica por ser um produto histórico e, como tal, inserido no conjunto de relações de forças que instituem e consolidam a ordem social ou o poder. Ser metafórica significa que possui vários sentidos que se entrecruzam, ou seja, é ambígua e dinâmica, podendo ser instrumentalizada conforme os interesses políticos em presença. Por outro lado, o ambíguo pode ser ainda aquilo que escapa à lógica e à coerência do sistema, aquilo que é inusitado, que gera perplexidade e pode, por suas características, colocar em questão toda a ordem instituída. Como se entende a partir do materialismo histórico, a realidade não é translúcida e o imediatamente dado, que aparece como o lado luminoso das relações sociais, esconde as contradições que o compõe e que precisam ser desveladas para que seu verdadeiro conteúdo (político, ideológico) transpareça.

Na medida em que se afirma o novo modo de existência da filosofia pela sua relação privilegiada com a história e a política, característica fundamental do materialismo histórico, tem-se que reconhecer a historicidade de toda concepção de mundo e as novas articulações que se estabelecem entre sujeito e objeto, consciência e realidade, conhecimento de si e do mundo. Tem-se ainda que assumir a metáfora como o modo de expressão privilegiado do discurso filosófico, vinculando-a aos princípios de tradutibilidade e conversibilidade. Uma definição de metáfora que encontramos no Caderno 11 afirma o seguinte: "pode-se dizer que a linguagem atual é metafórica com relação aos significados e ao conteúdo ideológico que as palavras tiveram nos períodos precedentes da civilização”. Não considerar esse fato, ou seja, do fato de "não se ter um conceito crítico e historicista 
do fenômeno linguístico derivam muitos erros, seja no campo da ciência quanto no campo prático" (Q. 11, p. 1427).

Nesse contexto, são as palavras e as linguagens traduzíveis e conversíveis, de modo que os pragmáticos erram ao "teorizar abstratamente sobre a linguagem como causa de erro" (G. PARETO, G. PREZZOLINI). A "linguagem se transforma com o transformar-se de toda civilização", com as mudanças culturais, com "a hegemonia exercida de uma língua nacional sobre outras, etc.” (Q. 11, p. 1427).

A tradutibilidade ocorre entre línguas e entre a linguagem e a prática; na luta por uma nova hegemonia cria-se também uma nova linguagem, pois ela é viva e traduz o movimento da realidade vivida. Uma filosofia que se manifesta como reflexão sobre a atividade humana e tem como objetivo precípuo a transformação dessa realidade, pode nascer de práticas não filosóficas e pode ainda converter-se em ação efetiva, ou seja, não pode ser formalizada, mas apenas traduzida.

Todo movimento cultural cria a sua linguagem própria, ou seja, participa no desenvolvimento geral de uma determinada língua nacional, introduzindo termos novos, enriquecendo com conteúdo novo os termos já em uso, criando metáforas, servindo-se de nomes históricos para facilitar a compreensão e o juízo sobre determinadas situações (políticas) atuais (Q. 29, p. 2264-2265).

A tradutibilidade designa a possibilidade de relação dos saberes entre si e destes com a atividade prática; se a filosofia, a política e a economia "são elementos constitutivos de uma mesma concepção de mundo, deve existir necessariamente, em seus princípios teóricos, conversibilidade de uma na outra, tradução recíproca na linguagem especifica de cada uma” (Q. 11, p. 1492-3). Esses saberes não são meros reflexos da infraestrutura, mas são traduzíveis entre si e apresentam uma conversibilidade com a prática, numa relação não redutora, mas produtiva, eficaz, transformadora. É a partir desse contexto que as classes subalternas podem, a partir de sua organização política e de sua linguagem própria, apropriar-se da cultura ou do conhecimento historicamente produzido, a fim de construir projetos transformadores da estrutura econômica, social e política.

Conforme Lacorte (2014, p. 61), a tradução entre linguagens "implica um trabalho político, no sentido amplo desta palavra, ou seja: um trabalho pedagógico-cultural, que se insere no quadro da transformação política da sociedade”. Para Gramsci, trata-se de explicitar a articulação entre teoria 
e prática a partir da leitura de Marx e de Lenin ${ }^{9}$, fazendo a crítica aos dois revisionismos que atingiram a filosofia da praxis: o determinismo mecanicista e o neoidealismo kantiano.

No curso dos Cadernos descortina-se uma metodologia histórica que explicita os fundamentos da dialética materialista e a relação concreta entre teoria e prática, a partir da qual a filosofia da praxis pode absorver outros paradigmas menores, como a filologia ou a linguística histórica.

Para Gramsci o materialismo histórico apresenta-se como a filosofia que, por ser "expressão necessária e inseparável de uma determinada ação histórica” (Q. 11, p. 1401-1402), por ser vivida na prática enquanto concepção de mundo, pelo seu compromisso com a transformação da realidade, por sua eficácia histórica, pode ser traduzida nas "linguagens das situações concretas particulares” e o movimento operário alemão pode ser apresentado como o "herdeiro da filosofia clássica alemã", um herdeiro que "continua praticamente o predecessor", porque "deduziu uma vontade ativa, transformadora do mundo, da mera contemplação” (Q 11, p. 1472-1473 e 1272) ${ }^{10}$. É somente nesse movimento relacional dialético entre teoria e prática que o conhecimento se realiza.

Na luta pela hegemonia, a questão do conhecimento e da linguagem são fundamentais para a conquista da direção intelectual e moral da sociedade. Daí a força hegemônica que emana do controle dos meios de comunicação de massa e da formação de um consenso passivo; no contexto da mundialização do capital e da fusão das grandes potências midiáticas, o controle autoritário e imperialista se instaura de modo sutil e quase imperceptível. Desconstruir esse processo e gerar novas bases de reflexão ou uma nova concepção de mundo torna-se um desafio como o de Sísifo ante a montanha ou de Édipo ante a esfinge.

E desconstruir implica seguir a senda de Marx, que partiu do contexto teórico produzido por economistas e filósofos da época para elaborar uma nova teoria crítica e transformadora. Nas aparências conciliadoras, Marx

9 Como exemplos, em Marx Gramsci salienta a relação efetuada entre a filosofia clássica alemã e a Revolução Francesa (Sagrada Família) e, em Lenin, a relação entre política e filosofia (um político escreve um livro de filosofia, mas a sua filosofia deve ser procurada na sua ação e nos seus escritos políticos).

10 No já citado Caderno 11, Gramsci (1978, p. 1471) retoma o curso da análise filológica de Croce sobre a comparação entre a linguagem política francesa e a linguagem filosófica alemã contida em A Sagrada Família; acentua que a expressão de Carducci: "Kant decapitou Deus - Robespierre, o Rei” foi retomada de Heine, mas a expressão original coube a Hegel em suas aulas de História da Filosofia e de Filosofia da História; nessas aulas, Hegel disse que "as filosofias de Kant, Fichte e Schelling continham a revolução em forma de pensamento" e que "somente os alemães e os franceses, por opostos que sejam entre si, ou precisamente porque opostos", conseguiram alcançar um grande momento da história universal. 
identificou as contradições; no contexto ideológico dominante, identificou os limites dos discursos e os interesses práticos que os sustentavam; destacou categorias e apropriou-se de conceitos para mostrar seus limites e superá-los a partir de sua articulação com a realidade efetiva. A partir de seu trabalho, transforma-se a filosofia e a teoria política para abrir novos horizontes de transformação.

Gramsci seguiu como ninguém essa senda, para mostrar que, no contexto das relações de hegemonia e da correlação de forças que caracteriza a luta de classes, esta se renova na medida em que o conhecimento se transforma em instrumento de dominação; o fato de a linguagem ser metafórica permite ressignificar as palavras conforme o momento histórico e a relação de forças em presença, ou seja, assim como os dominantes instrumentalizam a linguagem e a cultura para fins do exercício do poder, a organização política das classes subalternas se apresenta como o meio para elaborar a sua concepção de mundo, a sua cultura e a sua linguagem para assim se apropriar do conhecimento historicamente produzido. Sabe-se que se trata de uma relação extremamente desigual, mas a criação de formas de resistência não é impossível.

O possível precisa ser construído a partir da leitura crítica das condições presentes, ou seja, “do ponto de vista dos subalternos é necessário fazer a crítica da economia e da política burguesas, atuar no sentido da invenção da sociabilidade socialista" a partir da explicitação das condições presentes (DIAS, 2012, p. 133-134). Ou seja, inventar no interior da ação e do discurso burguês, rompendo os elos de subalternidade, criando uma linguagem própria, tirando proveito das possibilidades metafóricas a fim de refutar com destreza o universal legitimador do pensamento único e retomar o conhecimento na sua dimensão histórica.

Por exemplo, quando se fala em luta de classes tem-se que explicitar que o seu significado se transformou com a mundialização do capital: a luta de classes toma novas dimensões no contexto do capitalismo a partir do modo como se produzem e reproduzem as classes no movimento de produção dos modos de vida. Como acentua Dias, as classes "não são uma classificação topológica, mas articulações de luta, experiências e sociabilidades produzidas conflitivamente na sua oposição estrutural” (DIAS, 2012, p. 159). Nesse processo os "meios de comunicação de massa tornam-se decisivos na disputa hegemônica, alterando fundamentalmente o processo de luta de classes" (DIAS, 2012, p. 118). As formas de dominação se consolidam com base na 
formação de um modo de pensar homogêneo e pretensamente universal, diluindo as condições de expressão das classes subalternas.

Precisamos ter clareza de que "o real não é translúcido, não se revela ao puro olhar do investigador" (DIAS, 2007, p. 35), como querem fazer crer as tendências pós-modernas, concentradas no cotidiano e valorizando os relatos de experiência. $\mathrm{O}$ que nos aparece de imediato é sempre a ponta de um iceberg, uma imagem que oculta os elementos essenciais para a explicitação de seu significado. Para conhecer precisamos mergulhar nas aparências e buscar o que nelas se esconde; a verdade não se encontra em uma perspectiva, mas no verso e reverso da tessitura social, no visível que oculta o invisível, a forma e o conteúdo, a superfície e o abismo, num jogo de luzes e sombras.

Iluminar, para além das aparências, as contradições e as formas que elas assumem no processo de construção das condições materiais de existência, assim como as formas que assume a ideologia como prática de poder, supõe a organização política dos trabalhadores a fim de superar todas as ilusões e transformismos que minam já na origem qualquer tentativa de resistência frente aos mecanismos de poder. Trata-se de criar, nos embates políticos, as possibilidades de uma nova cultura e uma nova linguagem que possibilitem romper os elos de subordinação e as formas de marginalização que se proliferam na sociedade capitalista.

A questão que novamente se coloca nesses tempos de neoliberalismo é, na mesma assertiva que Jameson colocou para Lukács a proposito de História e Consciência de Classe, agora estendida para a esquerda: "mostrar que o pensamento proletário é exatamente capaz de resolver as antinomias que o pensamento burguês, pela sua própria natureza, é incapaz de enfrentar" (JAMESON, 1985, p. 146) ${ }^{11}$. E essa incapacidade do pensamento burguês se apresenta precisamente como limite ideológico ${ }^{12}$ na separação entre sujeito

11 A questão de fundo da leitura de Lukács, conforme Jameson (1985, p. 146) é mostrar como "alguma coisa na estrutura mesma do pensamento proletário dá acesso à totalidade ou realidade, ao conhecimento totalizante que era a pedra no caminho da filosofia burguesa clássica, com a resultante substituição do modelo estático de conhecimento, modelo do qual brotam os dilemas da burguesia. Algo deve ser encontrado na própria situação existencial do operário, que corresponda, como realidade concreta àquela união de sujeito e objeto, de conhecedor e conhecido, que Hegel propôs como solução ao problema kantiano da coisa-em-si no domínio do pensamento puro".

12 Lembramos A crítica de Marx a Hegel em O 18 Brumário de Luiz Bonaparte: "Hegel observa em uma de suas obras que todos os fatos e personagens de grande importância na história do mundo ocorrem, por assim dizer, duas vezes. Esqueceu-se de acrescentar: a primeira como tragédia e a segunda como farsa" (MARX, 1977, p. 17). O "esquecimento" de Hegel demonstra os limites da filosofia idealista e sua impossibilidade de conceber o movimento histórico real em suas contradições. Do mesmo modo, pode-se identificar o "esquecimento" de Ricardo que, nos limites da economia política que fundava suas reflexões, não podia falar da mais-valia. 
e objeto, na abordagem parcial e estática da história e da cultura limitada pelo pensamento abstrato, em todas as formas que assume, principalmente na valorização da linguagem em si, sem a sua devida articulação com a política. O problema de fundo é o de como colocar, no âmbito do historicismo, a questão da universalidade: somente o trabalhador, ao viver a condição de objeto e ao perceber-se como tal pode elaborar uma nova consciência de si que seja também uma consciência de classe, a partir da apreensão do real como processo e da unidade de pensamento e ação. Somente assim é possível compreender o real para além de suas aparências, o que implica uma efetiva organização política e a reformulação do entendimento sobre o processo pedagógico.

\section{Linguagem, concepção de mundo: a formação dos subalternos}

Nos períodos de crise, verificam-se as mais extensas e múltiplas manifestações de neolalismo (GRAMSCI, 1978, p. 2193).

A historicidade da linguagem e sua dimensão política que apresenta nas possibilidades de comunicação a partir da sua característica metafórica e como, a partir desse contexto, se pode construir a identidade dos subalternos. O materialismo histórico apresenta-se como uma nova filosofia que possui as condições de fazer a tradutibilidade das línguas, que designa a possibilidade de relação dos saberes entre si e destes com a realidade a partir do modo como entende a relação teoria e prática.

Iniciamos acentuando que Gramsci considera as mais variadas expressões da linguagem: falada e escrita e das artes em geral (música, pintura, arquitetura, etc.); o teatro apresenta-se como uma forma privilegiada de arte, porque alia várias linguagens expressivas (gesto, música, palavra, dança); de todas as maneiras a linguagem é pensamento e o expressar-se, na fala ou na arte, é sempre o esforço em fazer-se compreender e em comunicar um pensamento. No entanto, "há uma profunda diferença entre a expressão ‘verbal' e aquela das artes figurativas, da música, etc.”; essa diferença se acentua se entendida a partir dos elos nacionais e da tradição; os elementos sensíveis particulares mostram que, "sob a expressão de caráter 'cosmopolita' da linguagem musical, pictórica, etc.”, ou seja, nas formas de arte que assumem um caráter "[...]'internacional', existe uma substância cultural mais profunda e mais restrita, mais 'nacional-popular'[...]" (Q. 9, 1978, p. 1193), existe um elo entre os elementos universais que a música 
traduz e as características particulares da cultura que enraízam um povo em seu contexto histórico.

A arte tem uma característica universalizante e expressiva maior que a palavra, que tem um caráter mais estritamente nacional-popular; embora a oratória possa unir palavra, gesto e voz, ou seja "o elemento musical que comunica o leitmotiv do sentimento predominante" que articula razão e paixão, encontra-se também na oratória. Da perspectiva de uma história cultural, "existe entre a arte literária e as demais formas de expressão artística (figurativas, musicais, orquestrais, etc.) uma diferença que seria necessário definir e precisar de modo teoricamente justificado e compreensível”. Esse reconhecimento é fundamental para uma política cultural para as massas populares (Q. 9, p. 1194).

Essa especificidade da estética e das artes em geral não pode ser reduzida apenas a uma crítica política, embora a arte possa contribuir para a formação de tendências culturais que podem coincidir ou reforçar determinadas correntes políticas; por isso Gramsci prefere abordar esse problema no campo da história da cultura, concentrando-se na crítica literária.

A questão de fundo é que todo momento histórico-social é rico em contradições e cabe entender, do ponto de vista cultural e histórico, como interagem entre si a linguagem popular e a linguagem culta na atividade dos intelectuais, a fim de explicitar as várias formas de dominação. Cabe considerar que Gramsci trabalhava com o material que lhe chegava às mãos e em algumas ocasiões salientou que esses limites não lhe permitiam avançar pelos caminhos planejados.

Tomamos como ponto de partida as breves observações de Gramsci sobre os cantos populares, na formulação de Ermolao Rubieri, para dizer que existem três tipos de produção literária popular: 1) a composta "pelo povo e para o povo"; 2) a composta "para o povo, mas não pelo povo"; 3) a escrita "nem pelo povo nem para o povo", mas por este adotada, porque adequada à sua maneira de sentir e de pensar (Q. 5, p. 679).

Essa terceira categoria pode ser explicitada a partir do modo como Gramsci entende a formação de uma concepção de mundo e sua expressão na linguagem, como aparece no Caderno 11: “é preferível 'pensar' sem ter disso consciência crítica, de modo desagregado e ocasional, isto é, 'participar' de uma concepção de mundo 'imposta' mecanicamente pelo ambiente externo”, como o grupo social no qual estamos inseridos, a religião, as leis, a sabedoria das bruxas ou os intelectuais que dizem deter a posse do conhecimento, ou 
"é preferível elaborar a própria concepção de mundo consciente e criticamente" e, a partir daí, "escolher a própria esfera de atividade, participar ativamente na produção da história do mundo" sem aceitar passivamente que marquem, do exterior, a sua própria personalidade? (Q. 11, p. 13751376). Como se pode fazer a passagem da consciência espontânea para a consciência crítica? "Por que e como se difundem, tornando-se populares, as novas concepções de mundo?” Nesse processo interagem muitas variantes, "elementos que variam conforme o grupo social e o nível cultural" deste mesmo grupo. As massas populares mudam lentamente e nunca de forma "pura", ou seja, fazem combinações variadas e muitas vezes contraditórias. A forma racional, lógica e coerente, tem sua importância, mas não define o processo de mudança, que ocorre principalmente por razões políticas e sociais. Disso se conclui que "nas massas enquanto tais a filosofia não pode ser vivida senão como uma fé” (Q. 11, p. 1389-90).

Mesmo na solidão do cárcere, com material teórico restrito, Gramsci tenta criar uma imagem das condições empíricas que caracterizam a vida do trabalhador:

Imagine-se a posição intelectual de um homem do povo: ele se formou a partir das opiniões, das convicções, dos critérios de discriminação e das normas de conduta. Qualquer um que sustente um ponto de vista contrário ao seu, enquanto é intelectualmente superior e sabe argumentar as suas razões melhor que ele, consegue derrotá-lo logicamente; deveria ele, por isso, mudar as suas convicções? Porque não sabe fazer prevalecer sua opinião numa discussão? Se fosse assim poderia acontecer que devesse mudar de opinião uma vez ao dia, ou seja, todas as vezes que encontrasse um adversário ideológico intelectualmente superior. Em que elementos se funda, então, a sua filosofia? E especialmente a sua filosofia na forma que tem para ele maior importância, como norma de conduta? O elemento mais importante é, sem dúvida, de caráter não racional, de fé. Mas de fé em quem e em que coisa? Especialmente no grupo social ao qual pertence, enquanto este pensa difusamente como ele (Q. 11, p. 1390-1391).

Esse pensamento difuso, que agrega os indivíduos num grupo, não muda a partir da lógica ou da demonstração racional, mas sim por meio da ação política que une forças em torno de um objetivo comum. O homem de povo, mesmo que não consiga refutar os argumentos do adversário, acredita que "em tantos não se pode errar"; que "ele próprio, é verdade, não é capaz de sustentar e desenvolver as próprias razões, como o adversário sustenta e desenvolve as suas", mas em seu grupo existe quem poderia fazer uma argumentação convincente esclarecendo as razões de sua fé. As condições básicas de persuasão estão contidas nessa necessidade das pessoas simples 
de ancorarem em uma verdade que lhes garanta o sentido de viver e de lutar. As religiões têm-se aproveitado desse modo de viver uma concepção de mundo e repetem seus argumentos a exaustão, a fim de manter seus fiéis. Modificar esse cenário ideológico implica muito esforço e persistência para substituir o senso comum e as velhas concepções de mundo em geral. $\mathrm{O}$ método aconselhado por Gramsci na luta política por mudanças sociais é "não se cansar de repetir os próprios argumentos e criar os meios de elevar intelectualmente as camadas populares" criando "intelectuais de novo tipo, que surjam diretamente da massa e a ela permaneçam vinculados tornandose seu sustentáculo" (Q. 11, p. 1392).

Nesse contexto de luta hegemônica e de formação de novos intelectuais se insere a preocupação de Gramsci com a literatura popular e suas condições na história italiana dos séculos XIX e XX. Cabe explicitar o que Gramsci entendia por literatura nacional-popular ${ }^{13}$, dois conceitos que recebem um novo significado na leitura crítica do movimento político e cultural pela unificação italiana. A pergunta de Gramsci: o movimento "nacional que conduz à unificação do Estado italiano deve necessariamente desembocar no nacionalismo e no imperialismo nacionalista e militar?” A resposta é não, porque as tradições italianas, romanas antes e católicas depois, são cosmopolitas, embora isso não signifique que não se possa romper com as tradições. E isso é realmente viável, sendo a "expansão moderna de origem capitalista financeira”. A partir dessa argumentação, Gramsci acentua a correlação de forças entre capital e trabalho, para mostrar que, a partir dessas novas condições, "a tradição italiana continua dialeticamente no povo trabalhador e nos seus intelectuais”, de modo que o cosmopolitismo tradicional pode tornar-se internacionalismo, visto que "o povo italiano é aquele que 'nacionalmente' está mais interessado no internacionalismo" (Q. 9, p. 1190). Ou seja, o termo "nacional" vai sendo vinculado ao termo "popular" a partir do modo como se organiza a sociedade moderna, permeada pelas lutas de classes e pela forma como se organizam as relações de hegemonia que, da perspectiva do capitalismo financeiro, Gramsci vislumbra (embora não aprofunde) o seu desdobramento como imperialismo (Q. 9, p. 1192).

O nacional-popular define-se pela recusa ao cosmopolitismo e ao nacionalismo que predominaram na história italiana medieval e moderna para assumir um novo significado, como a expressão das contradições sociais a serem superadas na organização política dos trabalhadores, na

13 Abordarei brevemente esse termo, que já explicitei anteriormente, de modo que remeto ao meu livro intitulado Hegemonia e Cultura: Gramsci (SCHLESENER, 2007). 
sua forma mais moderna e avançada do internacionalismo. Desse modo, o conceito se expressa na cultura a partir de sua articulação política: Rafael, Verdi, assim como Dante, são populares porque a linguagem artística pode ser internacionalizada e nela os sentimentos confluem.

"Popular", por sua vez, é um adjetivo que aparece designando outros termos além de nacional como: cultura popular, literatura popular, teatro popular, canto popular, escritores populares, etc., todos eles sempre analisados no contexto histórico e político italiano. Assim, a literatura popular: primeiro, para que esta exista é preciso que haja uma identidade de concepção de mundo entre escritores e povo, isto é, que os intelectuais se identifiquem com os sentimentos, os objetivos e as expectativas das classes populares. A ausência de uma literatura nacional-popular na Itália evidencia o distanciamento entre os grupos intelectuais e a massa, fruto de um processo histórico sem grandes movimentos transformadores, no qual o paternalismo e o cosmopolitismo, de raízes imperial e católica, marcaram a formação das elites intelectuais, ora mantidas pelo mecenato, ora voltadas para atividades individuais ou cosmopolitas, sempre vinculados a uma tradição de casta, livresca e abstrata ${ }^{14}$.

Essa separação reflete-se no fato que o público italiano se interessa muito mais pela literatura estrangeira, que responde melhor a seus sentimentos e modo de vida. E esse fato revela características das relações de poder: "todo povo tem sua literatura, mas ela pode ser assimilada de um outro povo" e, do ponto de vista político, isso demonstra que esse povo se subordina a uma hegemonia intelectual e moral externa. Esse paradoxo se traduz em que "muitas tendências monopolistas, de caráter nacionalista e repressivo", que pretendem construir grandes hegemonias, "não se dão conta de serem objeto de hegemonia estrangeira, assim como, enquanto se fazem planos imperialistas, na realidade se é objeto de outros imperialismos, etc." (Q. 25, p. 2253). Essa colocação, embora breve, permite esclarecer como as relações de poder e de hegemonia se constroem a partir das mais variadas interrelações e como os intelectuais, com sua atitude livresca e abstrata, desconhecem o alcance e a profundidade política de suas funções.

Essa perspectiva abre novas questões para as classes subalternas, visto que a subalternidade se insere na dimensão das relações capitalistas

14 Estas análises da realidade intelectual italiana podem nos ajudar a compreender o distanciamento entre a literatura brasileira e as classes populares, da qual a intelectualidade permanece distante. O problema não é apenas o analfabetismo endêmico e funcional que atinge as classes trabalhadoras, que não lêem, mas o da formação de uma elite dirigente que olha e sonha com a realidade europeia ou a norte-americana. As massas que, em geral, não lêem, são cotidianamente formadas pelos canais abertos de televisão. 
internacionais. Os Cadernos 25 e 26 (assim como o 29), escritos em $1935^{15}$, nas idas e vindas entre o cárcere e a clínica, no final de suas forças, retomam anotações dos Cadernos 3 e 5 sobre a história e a cultura das classes subalternas, num esforço em mostrar um caminho de pesquisa ao historiador materialista. A questão de fundo é entender o movimento histórico e explicitar as várias formas de dominação que se consolidam no senso comum e na concepção de mundo sem articulação ou racionalidade crítica, fruto da ação, entre outros fatores, dos intelectuais.

Os grupos sociais subalternos têm seus cantos populares, mas a literatura é adotada, ou seja, assimilada daquela escrita por intelectuais que sabem expressar seus sentimentos e valores. Sem dúvida, "existe na atividade histórica desses grupos a tendência para a unificação" e ordenamento de seu saber desagregado e episódico, "mas esta tendência é continuamente destruída pela iniciativa dos grupos dominantes". Os "grupos subalternos sofrem sempre a inciativa dos grupos dominantes mesmo quando se rebelam"; somente "a vitória 'permanente' quebraria, e não imediatamente, os elos de subordinação” (Q. 25, p. 2283). A cultura, o modo de pensar, o modo como se naturalizam as relações, a assimilação de um pensamento homogêneo e da história escrita da perspectiva dos dominantes são os grilhões invisíveis que subordinam mesmo inconscientemente. Enquanto não se superar a fragmentação e descontinuidade do modo de pensar dos subalternos, enquanto não se esclarecerem os elos entre política e literatura e se superar a separação entre intelectuais e povo, esse não tem condições de produzir uma nova literatura popular. Para tal, precisa romper os elos de subordinação e criar uma nova concepção de mundo, o que acontece apenas no movimento de organização política (Q. 15, p. 1777-1779).

Gramsci vai mais além, dizendo que "ainda quando parecem triunfantes, os grupos subalternos estão apenas em estado de defesa alarmada"16. Por isso, "qualquer traço de iniciativa autônoma por parte dos grupos subalternos deveria ser de valor inestimável para o historiador integral” (eu diria, materialista). E reconhece que uma tal história é sempre difícil de escrever, principalmente porque o material é difícil de encontrar e recolher (Q. 25, p. 2283-84). Portanto, o esforço de Gramsci em fazer o levantamento da literatura popular pode ser vinculado ao seu empenho em levantar

15 Os Cadernos 25 e 26, já citados acima e compostos no mesmo período em que Gramsci organiza o Caderno 29 sobre a Gramática, são importantes para compreender a questão política que perpassa a leitura gramsciana da linguagem.

16 Gramsci cita como exemplo a história da Revolução francesa, ao menos até 1830. Um escrito básico para se entender esse exemplo seja O Dezoito Brumário de Luís Bonaparte, de Marx. 
o material para uma história dos grupos subalternos, como parte de um processo de formação de uma identidade de classe a partir da elaboração de um pensamento autônomo capaz de impulsionar uma ação inovadora, de ser a base de construção de uma nova sociabilidade.

"A unidade histórica das classes dirigentes tem lugar no Estado e a história deste é essencialmente a história dos Estados e dos grupos de Estados”. Uma unidade que não é apenas jurídica e política, mas é essencialmente "o resultado das relações orgânicas" entre sociedade política e 'sociedade civil', que constituem o Estado. As classes subalternas "não são unificadas e nem podem se unificar antes de se tornarem 'Estado'[...]”: a sua história, portanto, se confunde com a história da sociedade civil e, deste modo, faz parte da história dos Estados (Q. 25, p. 2287-2288). Essas observações antecedem a lista das fases que um historiador materialista precisa seguir para escrever a história das classes subalternas, um caminho detalhado e rigoroso que pode servir a qualquer pesquisador no seu trabalho de explicitar o real em suas múltiplas determinações:

Levantar: 1) a formação de grupos sociais subalternos pelo desenvolvimento e transformações que ocorrem no mundo da produção econômica, a sua difusão quantitativa e a sua origem a partir dos grupos sociais preexistentes, dos quais conservam, por um certo tempo, a mentalidade, a ideologia e os fins; 2) a sua adesão ativa ou passivamente às formações políticas dominantes, as tentativas de influenciar os programas destas formações para impor reivindicações próprias e as consequências que tais tentativas tem na determinação dos processos de decomposição e de renovação ou de nova formação; 3 ) o nascimento de novos partidos dos grupos dominantes para manter o consenso e o controle dos grupos subalternos; 4) as próprias formações dos grupos subalternos para reivindicações de caráter restrito e parcial; 5) as novas formações que afirmam a autonomia dos grupos subalternos, porém nos velhos quadros; 6 ) as formações que afirmam a autonomia integral, etc. (Q. 25, p. 2288)

Trata-se de um verdadeiro planejamento metodológico, como um legado de orientação a quem interessar um estudo profundo da história das classes subalternas. Um texto claro e preciso, no qual acentua que o "historiador deve observar e justificar a linha de desenvolvimento em direção à completa autonomia, desde as fases mais primitivas" até as manifestações de divisão, considerando sempre a complexidade dessas formações. Precisa explicitar o conjunto de relações de força, ou seja, as repercussões e os impactos que as ações dos grupos subalternos exercem sobre os grupos dominantes e as ações destes para manter o poder, ações "muito mais eficazes porque apoiadas pelo Estado". Um historiador deve ainda evidenciar as relações 
internas dos movimentos sociais e como, "entre os grupos subalternos, um exerce ou tende a exercer uma certa hegemonia por meio do partido”, de modo que cabe estudar as relações entre tendências e partidos, tanto das classes subalternas quanto dos grupos dominantes. "Muitos critérios de pesquisa podem ser elaborados a partir da análise das forças inovadoras" que prepararam o Risorgimento italiano (Q. 25, p. 2288-2289). Pode-se dizer o mesmo da Revolução francesa ou do nascimento da burguesia a partir das relações comunais medievais.

Fazer a história das classes subalternas tem um caráter pedagógico: como enfrentar de modo crítico o senso comum, mostrando seus limites ideológicos, sem ferir o sentimento popular? Como posicionar-se ante "as crenças e ilusões populares" (justiça, igualdade, fraternidade, ou seja, "elementos ideológicos difundidos pelas tendências democráticas herdeiras da Revolução francesa") de modo criativo e positivo? Com um "sarcasmo apaixonado", desvelando os limites reais dessas crenças de modo a dar-lhes uma nova forma inovadora (Q. 26, p. 2300).

Seguem-se recomendações, como ter o cuidado de "manter o contato com as expressões subalternas" das velhas concepções e, ao mesmo tempo, "acentuar a diferença daquelas dominantes e dirigentes", esperando que os novos conceitos, adquiridos no desenvolvimento histórico, alcancem a força de novas crenças populares. A atitude de quem usa o sarcasmo e, portanto, já se apropriou de novos conceitos, deve ser uma atitude polêmica, de quem levanta as contradições e salienta o movimento histórico no qual elas se produzem e podem ser superadas. “Por sua própria natureza, o 'historicismo' não pode exprimir-se de forma apodítica e doutrinária”, mas precisa criar uma nova linguagem como meio de luta intelectual. "O 'sarcasmo' aparece como o componente literário", com "exigências teóricas e práticas que podem superficialmente aparecer como insanavelmente contraditórias”; o critério metodológico de abordagem é a "passionalidade" que se expressa na sinceridade do educador (Q. 26, p. 2301).

De tudo o que se acentuou acima, salienta-se que um gramático não pode esquecer a história da língua e essa história se constrói no contexto de lutas políticas pelo poder ou pela hegemonia. Para Gramsci, esse foi o caso da língua italiana, a partir dos estudos de Dante Alighieri, que ele aborda, ainda que indiretamente, na sua leitura do Canto X, do Inferno. Gramsci insere-se num debate sobre a poesia dantesca já em 1918, quando publica no Avanti1 o artigo Il cieco Tiresia, no qual toma como motivo narrativas populares a respeito de previsões ocorridas no final da Primeira guerra, a 
partir de notícias de jornais sobre uma menina do interior da Itália que, depois de prever o final da guerra, ficou cega. O tema de fundo desse artigo, que retorna nos Cadernos, é a contraposição da chamada alta cultura (burguesa e católica) com a cultura popular. (Q. 6, p. 833-834).

Nas narrativas antigas, a cegueira é uma característica dos videntes e dos sábios. No Caderno 4 e 5, Gramsci acentua que na "tradição literária e no folclore o dom de previsão vem sempre vinculado a uma enfermidade atual do vidente que, embora veja o futuro, não vê o presente imediato porque cego". A crença na vidência é própria da cultura popular, enquanto a narrativa culta e refinada prefere dados mais racionais ou conforme a ordem natural das coisas. Tirésias éfruto da expressão popular e a sua experiência ressignificada por Dante no Canto $\mathrm{X}$ do Inferno, na figura de Cavalcante, implica a repercussão do popular na literatura culta (Q. 4, p. 527).

A língua italiana, de origem popular, torna-se ao longo da história italiana a língua dos intelectuais e da alta cultura, enquanto as classes subalternas se encerram nos dialetos de suas regiões. Explicitar essa história apresenta-se como um dos caminhos para acentuar a dimensão política e ideológica da linguagem, na formação de uma elite intelectual que constrói o discurso hegemônico e na submissão passiva dos subalternos, que aderem ao instituído sem perceber que, com isso, perdem as principais condições de autonomia porque perdem a sua voz.

Dias (2012, p. 67-69) acentua que o debate do início do século XX, firmava-se na "centralidade da relação intelectual-política" e que o movimento revolucionário europeu, incluindo a direção do Partido Social Democrata Russo, era constituído por intelectuais que foram seus principais dirigentes. Nesse contexto, o pensamento dos subalternos se elaborava a partir da voz do outro, que vinha da classe dominante. Daí a importância das observações de Gramsci sobre a necessidade de as classes subalternas formarem os seus próprios intelectuais.

"Quando se delega também no interior do partido, a direção partidária, a capacidade de pensar os projetos, as lutas, o subalterno continua subalterno". Dessa perspectiva, a "proposta gramsciana de partido é um escândalo radical diante da prática de socialistas e comunistas que vivem o fetichismo da organização" (DIAS, 2012, p. 70). Gramsci não nega a importância da organização política, mas defende intransigentemente a participação efetiva dos trabalhadores na estrutura interna do partido (sindicatos, etc.), 
na prática de uma democracia efetiva expressa na mobilidade de direção, tornando o partido uma escola de formação de dirigentes ${ }^{17}$.

Dessa perspectiva, a linguagem assume a sua verdadeira dimensão política, na crítica ao senso comum, na elaboração de uma nova concepção de mundo como instrumento de emancipação política, porque meio de superação ideológica, de educação para uma nova ordem social e política. A importância de uma reforma intelectual e moral a partir da formação de novos intelectuais orgânicos tem como pressuposto a dimensão política da linguagem e o envolvimento dos intelectuais com as massas.

Neste contexto, a ideologia permeia as relações sociais e políticas, formando a nossa subjetividade; nas agudas palavras de Pasolini, um intelectual solitário, leitor e também crítico do marxismo, encontramos a definição de burguesia e, por extensão, a ideia de indivíduo que se solidificou no senso comum:

Por burguesia não entendo tanto uma classe social quanto uma verdadeira doença. Uma doença muito contagiosa: tanto que ela contagiou quase todos os que a combatem. [...] O burguês - digamos espirituosamente - é um vampiro, que não fica em paz enquanto não morde sua vítima no pescoço, pelo puro, simples e natural prazer de vê-la se tornar pálida, triste, feia, desvitalizada, disforme, corrompida, inquieta, cheia de sentimentos de culpa, calculista, agressiva, terrorista, tal como ele mesmo (PASOLINI, 1982, p. 38).

O que Pasolini denuncia é a assimilação de pensamento e de comportamento próprios da burguesia, que os meios de comunicação de massa se encarregam de formar de um modo unívoco, ampliando a miséria da alienação a fim de fortalecer os laços inconscientes de submissão. Os meios de comunicação de massa nos tornam indiferenciados e indiferentes aos problemas e inclusive à existência de classes sociais antagônicas, menos ainda às lutas de classes.

Nesse contexto de leitura a crítica da linguagem e de seus efeitos políticos se apresenta como um dos momentos de elaboração do conceito de hegemonia, ou seja, na constituição e manutenção de uma elite de intelectuais capaz de elaborar um consenso ou de alimentar o senso comum com fragmentos de culturas mesclados com informações pretensamente neutras a fim de incentivar a aceitação do dado, a naturalização da história, a

17 Gramsci sempre se posicionou contra um partido burocratizado, que concentra a direção nas mãos de um grupo, fato evidenciado nas experiências do conselho de Fábrica e no jornal L'Ordine Nuovo, mais tarde explicitado na correspondência trocada com Togliatti em 1926 e retomada nos fragmentos dos Cadernos do Cárcere que abordam a questão do partido e do Estado. 
passividade ante o estabelecido, contribuindo para a estabilidade da prática social. Desenha-se assim a ideia de que existe uma verdade igual para todos, visto que, para ser "verdade", não pode se sustentar nem se referir à divisão de classes. Ela não existe, porque vive-se numa "democracia" onde todos são "iguais" perante a lei e usufruem dos mesmos direitos como indivíduos isolados; para Eagleton (1997, p. 196-197) estabelece-se aqui uma das fortes fontes de hegemonia consolidada no sistema parlamentar, ou seja, "supostamente, as pessoas acreditam governar a si mesmas, crença esta que não se esperaria ver alimentada por nenhum escravo da Antiguidade ou servo medieval". Gramsci ampliou, por meio do conceito de hegemonia, a noção de ideologia, que tomou "corpo material e agudeza política" ao ser transposta para a prática social cotidiana podendo abranger "dimensões inconscientes e não articuladas da experiência social”.

Eagleton (1997, p. 107) define a hegemonia como uma gama de "estratégias práticas pelas quais um poder dominante obtém o consentimento ao seu domínio daqueles que subjuga". Acrescentamos que esse consentimento pode ser inconsciente, na medida em que as relações sociais são naturalizadas e a divisão de classes diluída por meio das ideias de igualdade e liberdade individual, assimiladas no curso do processo educativo; para explicitar as relações de hegemonia torna-se necessário mostrar que a linguagem radica-se na estrutura da sociedade, tem raízes histórico-sociais e, portanto, é ideológica e funciona como instrumento de poder e de dominação.

A divulgação de uma ideologia unificadora, ao lado do controle ideológico pelas diversas vias que compõe a divulgação do "saber" na forma de informação, atua para consolidar a alienação na qual estamos imersos, cuja superação implica um movimento efetivo de organização política, que caminhe pari passu com a superação da fragmentação que caracteriza o modo de pensar dos subalternos. Muito além do que propõe os pragmáticos, a linguagem tem uma função central nesse processo e falar de linguagem implica remeter-nos à questão da educação.

Concentramo-nos na questão da linguagem por entendermos fundamental explicitar a sua dimensão ideológica no contexto dos escritos de Marx e Gramsci, a fim de salientar que a dialética marxista se constrói a partir da empiria e do modo de produção (trabalho) e não da linguagem, embora se possa fazer recortes do texto de Marx para dizer o contrário. Pensamos ter esclarecido implicitamente no corpo de nosso texto a amplitude do desafio educativo e formativo a enfrentar no contexto da sociedade capitalista contemporânea, não apenas como um desafio dos pedagogos, 
mas de todos os intelectuais que se dizem leitores de Marx. Um desafio que passa pela reorganização dos movimentos populares e que se apresenta na nova dimensão da luta de classes enquanto uma luta econômica, política e cultural. A exposição até aqui desenvolvida nos possibilita, agora, abordar a questão da educação.

A importância da educação formal se apresenta no fato que a luta de classes assume uma dimensão ideológica sempre mais acentuada e a fragilidade das classes subalternas se sedimenta precisamente no fato de não terem condições de sistematizar seu pensamento contra o pensamento dominante e de somente poderem fazê-lo a partir da consolidação de sua organização política. $\mathrm{O}$ fato de haverem fracassado em suas lutas no curso da história não significa que suas reivindicações não eram válidas; a derrota, porém, traz consigo a perda das condições de possibilidade de articular num pensamento coerente as ações realizadas a fim de se contrapor a uma leitura histórica hegemônica.

A dialética supera a lógica formal, mas não abole a sua necessidade e a escola é a única instituição burguesa que possibilita o acesso a esses códigos de raciocínio e de domínio do conhecimento, básicos para ir adiante na formulação de um pensamento crítico. 